\title{
Austerity policies in the Eurozone: How they affect youth unemployment?
}

\author{
Carmen DIAZ-ROLDÁN
}

\author{
Universidad de Castilla-La Mancha, Spain
}

\author{
José Luis PARADA-RODRIGUEZ, Nieves CARMONA-GONZÁLEZ \\ Universidad Francisco de Vitoria, Spain
}

\begin{abstract}
:
Aim: Analyse the effects of stabilization policies on youth unemployment, using government deficit besides the use of fiscal policy by the supply side; aimed to characterize the economic framework conditions under which fiscal policy could reduce youth unemployment.

Design/Research methods: We consider an economic framework featuring the use of monetary and fiscal rules within a monetary union. In this scenario, that should be representative of the Eurozone, we will analyse the effects of stabilization policies when dealing with a financial crisis which produces contractive effects on output and on employment. We will pay special attention to the conservativeness of the central bank, the degree of austerity of the fiscal authorities and the initial level of government debt. Those characteristics prove to be crucial for the sustainability of economic policies packages based on fiscal consolidation and the use of fiscal policy instruments by the supply side, when trying to deal with unemployment. And given that in the financial crisis effects have been hit Eurozone countries in a different manner, we will also differentiate monetary union's member countries according with their government debt and their unemployment path.
\end{abstract}

Conclusions/findings: Fiscal authorities should be no austere for fighting youth unemployment, when using fiscal policy by the supply side. In other words, when optimizing their loss function, they should give more weight to the output stabilization goal that to the government deficit reduction.

Originality/value of the article: Allowing for the use of both monetary and fiscal policy rules, in the scenario of a monetary union, our results could help us to stablish the conditions under which fiscal policy could help to alleviate youth unemployment.

Key words: Monetary unions, fiscal consolidation, sustainable policies, youth unemployment.

JEL Codes: E62, E63, H6

Correspondence address: Carmen DIAZ-ROLDÁN Universidad de Castilla-La Mancha, Spain. E-mail: carmen.diazroldan@uclm.es

Received: 13.07.2018, Revised: 24.11.2018, Accepted: 24.11.2018

doi: http://dx.doi.org/10.29015/cerem.753 


\section{Introduction}

The process of job destruction, spread worldwide, which began after the crisis initiated in 2007, has had a particularly negative effect on youth unemployment. This was already a structural problem in several countries, mainly developing and peripheral ones, which has been aggravated by the crisis. Youth unemployment, by affecting the economic situation of the younger population, compromises the potential growth and the sustainability of the economy. The goal number 8 of the Sustainable Development Goals (SDGs) of the United Nations pursues "decent work and economic growth", and among its targets are (i) the full employment of young people, (ii) the reduction in the proportion of young people who are neither working nor studying, and (iii) the implementation of a strategy to boost youth employment (Gómez et al. 2016).

In the Eurozone, the financial crisis effects have been hit countries in a different manner. Certain groups of the periphery have showed more vulnerable, producing alarming figures on output decreases and unemployment increases, particularly those of youth unemployment. This compromise the inter-generational aspects of sustainable growth and development.

These problems become particularly relevant in the case of the member countries of a monetary union facing a sovereign debt crisis, given that fiscal policy is the only domestic stabilization policy, and also is constrained by the need to carry out fiscal consolidation and reduce debt levels. The pre-existing national different fiscal frameworks need to be consistent with the requirements of discipline at the union level and should be supported by an appropriate design of structural policies. But even in a set of integrated economies as the European Union (EU) and the Eurozone prove to be, the policies measures adopted for recovering after the crisis become of special relevance. For that reason, the social policy of the EU is committed to a strategy of active inclusion of people excluded from the labour market, in the fight against poverty and social exclusion; identifying as critical the link between social vulnerability and youth unemployment (European Commission 2008). And for contributing to the recovery of the recent crisis, based on the Juncker 
Plan, the European Fund for Strategic Investments (EFSI) is aimed to promote jobs and sustainable development (European Commission 2017).

As was addressed by Blanchard (2004), the evolution of the average European unemployment rate hides large cross-country differences and the path of unemployment have been very different across countries. One of the reasons is that in the European Monetary Union (EMU), the member countries are characterized by the diversity of their labour markets. And given that labour market institutions differ across European countries, macroeconomic shocks, institutional changes, and international integration influence unemployment changes (Bertola 2017). During the last decade, the Great Recession has had a profound impact. In 2017, youth unemployment (less than 25 years) in Germany, at 6.70\%, was the lowest of the Eurozone countries (18.33\% in average), followed by the Netherlands at $8.87 \%$. By contrast, the highest figures have been reached by Greece, 43\%, and Spain, 38\% (Eurostat).

Having these considerations in mind, Díaz-Roldán (2018) has recently conducted an exercise for evaluating the use of fiscal policies by the supply side (FPSS) in heterogeneous monetary unions. The results support the traditional Phillips Curve predictions on inflation and unemployment relationship, while the use of fiscal policies by the supply side are not always advisable for stabilization purposes.

In this paper, we will analyse, in strategic terms, the effects of stabilization policies on unemployment, using government deficit besides the use of FPSS. After calculating changes on unemployment figures, our results will characterize the economic framework conditions under which FPSS could reduce unemployment.

To that aim, we will made use of a simple model for a monetary union (DíazRoldán 2017) using explicit policy rules and allowing for a more or less conservative governor of the central bank. We will also consider both an austere and no austere fiscal policy and, finally, we will take into account the initial level of public debt of the member countries of the union. Our analysis will focus on the collective affected by youth unemployment, since compromise the inter-generational aspects of sustainable growth and development. 
In order to highlight the effects of the diversity of labour markets and economic frameworks among EMU members, in this paper, we will perform an empirical application for three sets of European countries: the core, the peripheral, and the Eastern countries. The first group will be formed by five of the six founding states of the current EU, namely Belgium, France, Germany, Luxembourg and Netherlands. Those countries, known as the core of the EU, have shown relatively sustainable macroeconomic results after the recent crisis (Ahlborn, Wortmann 2017).

Nevertheless, among the current 19 countries of the EMU, some of them exhibit both high national budget deficits relative to GDP, and rising government debt levels: namely Portugal, Italy, Greece and Spain. Those are the southern and peripheral European countries, and they have been grouped, in Anglo jargon, as PIGS; although in 2008, it became PIIGS when Ireland was added after her banking crisis. For highlighting the relevance of high government deficits and debt level, for the recovery after the crisis, the peripheral European countries (PIIGS) will be our second group of analysis when performing the empirical application.

Our third set of countries will be constituted by the EMU counties belonging to the Central and Eastern European (CEE) countries. Those countries, grouping the former socialist countries of Europe, experienced significant growth after their accession to the EU which led to a high potential for convergence with their Western EU partners but, sometimes, at the cost of unsustainable external positions. Trying to test the export-led growth hypothesis Bajo-Rubio and Díaz-Roldán (2009) found that the Baltic states (in particular Latvia and Lithuania), showed external deficits potentially unsustainable in the long run and they also suffered a great fall in their rates of growth. Recently, after the economic crisis some of them have recovered their external disequilibria, although the fiscal consolidation required for recovering would mean a brake on their process of growth and convergence.

The paper structures as follows: the next section is dedicated to show the modelling strategy, next we will perform an empirical application discussing the results. Finally, in the concluding remarks we will summarize the main findings and their policy implications. 


\section{Modelling strategy}

In this section, we will follow the approach by Díaz-Roldán (2017). The departure point is a two-country aggregate demand-aggregate supply model describing a small monetary union formed by two symmetric countries. The single monetary authority (i.e., the central bank) of the union follows a Taylor-type monetary rule aimed to achieve the inflation targeting goal. Full delegation of prices control to the monetary authority of the union is assumed. Consequently, the government deficit will be the only demand policy instrument available at the country level. By solving the model, the reduced-form equations for the output levels and inflation rates of the two countries are obtained. These reduced-form equations depend on the fiscal policy instruments, as well as an exogenous countryspecific shocks to aggregate demand (hitting consumption, investment, trade balance, and money market) and supply (changing wage- and price-push factors, labour force, and productivity). In the set of equations which form the macroeconomic model, we allow for (i) a fiscal policy or a demand shock: i.e., variations in consumption or investment, changes of the trade balance, or any monetary policy; and (ii) a supply shock: i.e., an exogenous fluctuation in wages or prices, or a change in labour force or productivity; as well as any kind of fiscal policy applied by the supply side, such changes on contributions paid by employees, social security contributions by employers, payroll taxes, or indirect taxes.

Given the countries' economic structure, summarized in the corresponding reduced-form equations of the model, the fiscal authorities of each member country of the monetary union will proceed to minimize both changes in output, with stabilization purposes, and changes in the government deficit; to achieve budgetary discipline, given their loss function. In this framework, among the set of policy makers decisions, the use of a fiscal rule in both countries is allowed. The rule relates the achievement of the government deficit goal with the public debt path and the output level of each country. The explicit use of fiscal rules describes the current situation of EU fiscal governance, since the European Commission has enforced fiscal policy coordination and the use of numerical fiscal rules (see ECB 2013, for 
an analysis). Solving the optimization problem, we will obtain the optimal (fiscal) policy, i.e., the optimal level of public deficit compatible with the stabilization goal.

\section{Empirical application}

\subsection{The baseline model}

To illustrate the current situation faced by the Eurozone countries, in the empirical application we have computed the values for the case of a common demand contractive shock, leading to contractive effects on output and prices, and provoking a rise on unemployment figures.

For doing that, we have adopted the following assumptions. The shocks suffered by the countries have been normalized to 1 , so they are perfectly symmetric in size, although the shocks may differ in their sign, being perfectly asymmetric in their effects. Next, we will give numerical values to the parameters of the equations describing the model features (see Diaz-Roldán 2017 for details).

(1) In the monetary rule: we will assign a relatively high value to the weight of the inflation goal, to characterize a more conservative central banker.

(2) In the fiscal rule, we will describe a "disciplined" scenario in which there is a greater concern about deviations of debt and accumulated deficit than about deviations in production, aimed to fulfil fiscal consolidation supranational requirements as can be observed in the Eurozone.

(3) In the loss function we would assume that fiscal authorities could be more concerned about fiscal discipline or, on the contrary, they could be more concerned about output growth, to characterize a more austere or less austere national fiscal authority.

After solving the optimization problems for the cooperative and the noncooperative solution of the fiscal authorities, we obtain the optimal solution for the budget deficits, and we are also able to calculate the corresponding values of output and inflation. Additionally, we calculate the percentage of change of the unemployment rate $u$, when none FPSS is applied; and we calculate also the percentage of change of the unemployment rate $u_{\mathrm{F}}$, when the fiscal authority applies 
any kind of FPSS (changes on contributions paid by employees, social security contributions by employers, payroll taxes, or indirect taxes). The numerical results for unemployment are reported in Table 1 . Given the variables of the model are defined as logarithmic deviations from their equilibrium levels, and the values of the shocks have been normalized to 1 , the figures of the tables should be interpreted as deviation points from the equilibrium level. To the extent that our variable of interest is unemployment, figures on table 1 can be interpreted as the increase (+) or decrease (-) of the deviation of the actual unemployment rate from the NAIRU.

According to that, we will obtain different macroeconomic results depending on: (i) the degree of austerity of fiscal authorities' attitude, (ii) the initial level of government debt of countries; (iii) and the way in which fiscal authorities solve their optimization problem: in a cooperative or in an individual manner.

In Table 1 we can see the deviations of total unemployment using or not FPSS, under different macroeconomic scenarios. As have been explained above, the scenarios differ depending on the fiscal authorities' decision (cooperative of no cooperative), their preferences (austere or no austere), and the initial level of government debt.

\section{Table 1. Total unemployment}

\begin{tabular}{|c|c|c|}
\hline \multicolumn{3}{|c|}{ Cooperative solution } \\
\hline \multirow{3}{*}{ austere } & high debt & low debt \\
\hline & $u=7.18$ & $\boldsymbol{u}=-8.64$ \\
\hline & $u_{F}=9.15$ & $\boldsymbol{u}_{F}=-16.09$ \\
\hline \multirow{2}{*}{$\begin{array}{c}\text { no } \\
\text { austere }\end{array}$} & $u=11.74$ & $\boldsymbol{u}=-7.16$ \\
\hline & $u_{F}=14.49$ & $\boldsymbol{u}_{\boldsymbol{F}}=-29.76$ \\
\hline \multicolumn{3}{|c|}{ Non cooperative solution } \\
\hline \multirow{3}{*}{ austere } & high debt & low debt \\
\hline & $\boldsymbol{u}=-2.73$ & $u=3.00$ \\
\hline & $\boldsymbol{u}_{\boldsymbol{F}}=-7.37$ & $u_{F}=6.04$ \\
\hline \multirow{2}{*}{$\begin{array}{c}\text { no } \\
\text { austere }\end{array}$} & $\boldsymbol{u}=-4.04$ & $u=5.88$ \\
\hline & $\boldsymbol{u}_{F}=-12.09$ & $\boldsymbol{u}_{\boldsymbol{F}}=11.76$ \\
\hline
\end{tabular}

Source: Own elaboration based on the model by Díaz-Roldán (2017) and the described scenario.

Notes: $\boldsymbol{u}=$ total unemployment without using fiscal policy by the supply-side

$\boldsymbol{u}_{\boldsymbol{F}}=$ total unemployment after applying any fiscal policy by the supply-side 
As can be seen, the best result (the biggest decrease of the deviation) is obtained when fiscal authorities act in a cooperative manner, have no austere preferences, apply FPSS, and both countries show low debt figures. On the contrary, the worst result is produced when countries show high debt figures and the fiscal authorities cooperate. In the face of high debt levels, the no cooperative decision, joint with no austere preferences, proves to be the best.

\subsection{Empirical application to the Eurozone}

Since we are interested on the collective affected by youth unemployment in the Eurozone, we will show the changes of the figures reported in Table 1 if we apply those qualitative results to Eurozone members. As we mentioned in the Introduction section, in the Eurozone, the financial crisis effects have been hit countries in a different manner. For that reason, we will differentiate three sets of countries: the core, the peripheral and the Eastern countries ${ }^{1}$. Those groups have not shown the same macroeconomic trend after the recent crisis, especially if we look at their public finances. In Table 2 we can see the average of government debt. The countries grouped as PIIGS, show figures three times higher than the CORE countries ten years after the crisis.

Table 2. Gross government debt, average, percentage GDP year 2017

\begin{tabular}{|c|c|c|c|}
\hline Eurozone & CORE & PIIGS & CEE \\
\hline 86.70 & 68.78 & 120.45 & 42.66 \\
\hline
\end{tabular}

Source: Eurostat.

As showed in Table 3, the youth unemployment in PIIGS countries, doubles the figure of youth unemployment in the CORE countries in the same year 2017.

\footnotetext{
${ }^{1}$ Eurozone countries: Austria, Belgium, Cyprus, Estonia, Finland, France, Germany, Greece, Ireland, Italy, Lithuania, Luxembourg, Malta, the Netherlands, Portugal, Slovakia, Slovenia and Spain. CORE countries: Belgium, France, Germany, Luxembourg, the Netherlands. PIIGS countries: Portugal, Ireland, Italy, Greece, Spain. CEE countries belonging to Eurozone: Estonia, Latvia, Lithuania, Slovak Republic, Slovenia.
} 
Table 3. Percentage of active population (seasonally adjusted data) of youth unemployment (less than 25 years), year 2017

\begin{tabular}{|c|c|c|c|}
\hline Eurozone & CORE & PIIGS & CEE \\
\hline 18.33 & 14.54 & 31.10 & 14.51 \\
\hline
\end{tabular}

Source: Eurostat.

Taking into account the percentage of youth unemployment, according to Table 3 , we have computed the percentage of change of the youth unemployment rate when none FPSS is applied; and the percentage of change of the youth unemployment rate, when the fiscal authority applies any kind of FPSS.

The obtained results for total unemployment, showed in Table 1, hold when looking at total youth unemployment of the Eurozone (Table 5). In qualitative terms, the results are equivalent when we split the Eurozone in three sets of countries (the CORE, the PIIGS and the CEE countries), as we can see in Tables 6 to 8 .

Table 5. Youth unemployment total Eurozone (19) countries

\begin{tabular}{|c|l|l|}
\hline \multicolumn{2}{|c|}{ Cooperative solution } \\
\hline \multirow{4}{*}{ austere } & \multicolumn{1}{|c|}{ high debt } & \multicolumn{1}{c|}{ low debt } \\
\cline { 2 - 3 } & $\boldsymbol{u}=1.32$ & $\boldsymbol{u}=-1.58$ \\
\cline { 2 - 3 } $\begin{array}{c}\text { no } \\
\text { austere }\end{array}$ & $\boldsymbol{u}_{F}=1.68$ & $\boldsymbol{u}_{F}=-2.95$ \\
\cline { 2 - 3 } & $\boldsymbol{u}_{F}=2.66$ & $\boldsymbol{u}=-1.31$ \\
\hline \multirow{2}{*}{ Non cooperative solution } \\
\hline \multirow{2}{*}{ austere } & \multicolumn{1}{|c|}{ high debt } & \multicolumn{1}{|c|}{ low debt } \\
\cline { 2 - 3 } & $\boldsymbol{u}=-0.50$ & $\boldsymbol{u}=0.55$ \\
\cline { 2 - 3 } no & $\boldsymbol{u}_{F}=-1.35$ & $\boldsymbol{u}_{F}=1.11$ \\
\hline austere & $\boldsymbol{u}=-0.74$ & $\boldsymbol{u}_{F}=2.16$ \\
\cline { 2 - 3 } & $\boldsymbol{u}_{F}=-2.22$ & \\
\hline
\end{tabular}

Source: Own elaboration based on Table 1 and data obtained from Eurostat.

Notes: $\boldsymbol{u}=$ youth unemployment without using fiscal policy by the supply-side

$\boldsymbol{u}_{\boldsymbol{F}}=$ youth unemployment after applying any fiscal policy by the supply-side 
Table 6. Youth unemployment CORE Eurozone countries

\begin{tabular}{|c|c|c|}
\hline \multicolumn{3}{|c|}{ Cooperative solution } \\
\hline \multirow{3}{*}{ austere } & high debt & low debt \\
\hline & $\boldsymbol{u}=1.04$ & $u=-1.26$ \\
\hline & $\boldsymbol{u}_{F}=1.33$ & $\boldsymbol{u}_{F}=-2.34$ \\
\hline \multirow{2}{*}{$\begin{array}{c}\text { no } \\
\text { austere }\end{array}$} & $\boldsymbol{u}=1.71$ & $\boldsymbol{u}=-1.04$ \\
\hline & $\boldsymbol{u}_{F}=2.11$ & $\boldsymbol{u}_{F}=-4.33$ \\
\hline \multicolumn{3}{|c|}{ Non cooperative solution } \\
\hline \multirow{3}{*}{ austere } & high debt & low debt \\
\hline & $\boldsymbol{u}=-0.40$ & $u=0.44$ \\
\hline & $\boldsymbol{u}_{\boldsymbol{F}}=-1.07$ & $\boldsymbol{u}_{\boldsymbol{F}}=0.88$ \\
\hline \multirow{2}{*}{$\begin{array}{c}\text { no } \\
\text { austere }\end{array}$} & $\boldsymbol{u}=-0.59$ & $\boldsymbol{u}=0.85$ \\
\hline & $\boldsymbol{u}_{\boldsymbol{F}}=-1.76$ & $\boldsymbol{u}_{F}=1.71$ \\
\hline
\end{tabular}

Source: Own elaboration based on Table 1 and data obtained from Eurostat.

Notes: $\boldsymbol{u}=$ youth unemployment without using fiscal policy by the supply-side $\boldsymbol{u}_{\boldsymbol{F}}=$ youth unemployment after applying any fiscal policy by the supply-side

\section{Table 7. Youth unemployment PIIGS Eurozone countries}

\begin{tabular}{|c|c|c|}
\hline \multicolumn{3}{|c|}{ Cooperative solution } \\
\hline \multirow{3}{*}{ austere } & high debt & low debt \\
\hline & $u=2.23$ & $\boldsymbol{u}=-2.69$ \\
\hline & $u_{F}=2.85$ & $\boldsymbol{u}_{F}=-5.00$ \\
\hline \multirow{2}{*}{$\begin{array}{c}\text { no } \\
\text { austere }\end{array}$} & $u=3.65$ & $\boldsymbol{u}=-2.23$ \\
\hline & $\boldsymbol{u}_{F}=4.51$ & $\boldsymbol{u}_{F}=-9.26$ \\
\hline \multicolumn{3}{|c|}{ Non cooperative solution } \\
\hline \multirow{3}{*}{ austere } & high debt & low debt \\
\hline & $\boldsymbol{u}=-0.85$ & $\boldsymbol{u}=0.93$ \\
\hline & $\boldsymbol{u}_{\boldsymbol{F}}=-2.29$ & $\boldsymbol{u}_{F}=1.88$ \\
\hline \multirow{2}{*}{$\begin{array}{c}\text { no } \\
\text { austere }\end{array}$} & $\boldsymbol{u}=-1.26$ & $u=1.83$ \\
\hline & $\boldsymbol{u}_{F}=-3.76$ & $u_{F}=3.66$ \\
\hline
\end{tabular}

Source: Own elaboration based on Table 1 and data obtained from Eurostat.

Notes: $\boldsymbol{u}=$ youth unemployment without using fiscal policy by the supply-side $\boldsymbol{u}_{\boldsymbol{F}}=$ youth unemployment after applying any fiscal policy by the supply-side 
Table 8. Youth unemployment CEE Eurozone countries

\begin{tabular}{|c|l|l|}
\hline \multicolumn{3}{|c|}{ Cooperative solution } \\
\hline \multirow{4}{*}{ austere } & \multicolumn{1}{|c|}{ high debt } & \multicolumn{1}{c|}{ low debt } \\
\cline { 2 - 3 } & $\boldsymbol{u}=1.04$ & $\boldsymbol{u}=-1.25$ \\
\cline { 2 - 3 } $\begin{array}{c}\text { no } \\
\text { austere }\end{array}$ & $\boldsymbol{u}_{F}=1.33$ & $\boldsymbol{u}_{F}=-2.33$ \\
\cline { 2 - 3 } & $\boldsymbol{u}_{F}=2.10$ & $\boldsymbol{u}=-1.04$ \\
\hline \multicolumn{3}{|c|}{ Non cooperative solution } \\
\hline \multirow{4}{*}{ austere } & \multicolumn{1}{|c|}{ high debt } & $\boldsymbol{u}_{F}=-4.32$ \\
\cline { 2 - 3 } & $\boldsymbol{u}^{2}=-0.40$ & $\boldsymbol{u}=0.44$ \\
\cline { 2 - 3 } & $\boldsymbol{u}_{F}=-1.07$ & $\boldsymbol{u}_{F}=0.88$ \\
\hline \multirow{2}{*}{ no } & $\boldsymbol{u}=-0.59$ & $\boldsymbol{u}=0.85$ \\
\cline { 2 - 3 } austere & $\boldsymbol{u}_{F}=-1.75$ & $\boldsymbol{u}_{F}=1.71$ \\
\hline
\end{tabular}

Source: Own elaboration based on Table 1 and data obtained from Eurostat.

Notes: $\boldsymbol{u}=$ youth unemployment without using fiscal policy by the supply-side $\boldsymbol{u}_{\boldsymbol{F}}=$ youth unemployment after applying any fiscal policy by the supply-side

But according to data on Table 2, we could characterize the CORE and the CEE countries as "low debt" countries, given they are below the Eurozone average. On the contrary, we wold say that PIIGS countries are "high debt" ones, given they show a government debt above the Eurozone average. As stressed by Rozmahel et al. (2014) the division between CORE, periphery and CEE countries is obvious. And they also show slow and steady convergence of CEE towards the CORE countries regarding infrastructure and human capital.

Having this consideration in mind, and looking at Tables 6 to 8, our results would indicate that:

- For the CORE and the CEE countries, the best solution to fighting youth unemployment would be given by the cooperation among their fiscal authorities (when having decisions on the optimal level of government deficit), act in a no austere manner (showing a growth promoting preferences) and use any kind of fiscal policy by the supply side.

- For the PIIGS countries, the best solution would be no cooperation among fiscal authorities (i.e., not to implement the same objective for government 
deficit when managing fiscal policy at country level); act in a no austere manner and use any kind of fiscal policy by the supply side.

Notice that under our model assumptions (conservative central banker, and the use of a disciplined fiscal rule aimed to achieve fiscal consolidation), fiscal authorities should be no austere for achieving better results when fighting youth unemployment. In other words, when optimizing their loss function, they should give more weight to the output stabilization goal that to the government deficit reduction.

Moreover, following the assumptions of the model, the optimal decision of fiscal authorities depends on the effects of the initial government debt level. As stressed by Barrios et al. (2010), that estimated the determinants of successful fiscal consolidation, government debt level plays a significant role in achieving a successful fiscal consolidation. For that reason, given we have split Eurozone countries according to their macroeconomic performance, we obtain that the optimal policy (coordinated or no coordinated) is related to the level of government debt. Depending of that level, countries should apply or not the same objective for government deficit; leading to the implementation of different kind of fiscal policies and fiscal policies by the supply side. Those results would be in line with Picatoste et al. (2016), who conclude that policy makers should decide to apply different legal regulations affecting workers or firms.

\section{Concluding remarks}

In this paper, we have analysed the effects of stabilization policies on youth unemployment, using government deficit besides the use of fiscal policy by the supply side; aimed to characterize the economic framework conditions under which fiscal policy could reduce youth unemployment in a monetary union.

To that aim, we have considered an economic framework featuring the use of monetary and fiscal rules within a monetary union. In this scenario, that should be representative of the Eurozone, we have analysed the effects of stabilization policies when dealing with a financial crisis having contractive effects on output. We have 
payed special attention to the conservativeness of the central bank, the degree of austerity of the fiscal authorities and the initial level of public debt. Those characteristics prove to be crucial for the sustainability of economic policies packages based on fiscal consolidation and the use of fiscal policy instruments by the supply side.

But in the Eurozone, the financial crisis effects have been hit countries in a different manner. Certain groups of the periphery have showed more vulnerable, producing alarming figures on output decreases and unemployment increases, particularly those of youth unemployment. This compromise the inter-generational aspects of sustainable growth and development. For that reason, in our analysis, we have differentiated monetary union's member countries according with their macroeconomic performance.

According to our results, the CORE and the CEE countries, when fighting youth unemployment should coordinate their fiscal authorities' decisions, act in a no austere manner and they should use any kind of fiscal policy by the supply side. On the contrary, the PIIGS countries, should manage their fiscal policies in an individual way, act in a no austere manner and they also should use any kind of fiscal policy by the supply side. Those optimal policies prove to be related to the level of government debt, which reinforces the idea that fiscal consolidation is not a trivial question regarding the performance of the Eurozone. 


\section{Carmen DIAZ-ROLDÁN et al.}

\section{References}

Ahlborn M., Wortmann M. (2017), Output gap similarities in Europe. Detecting country groups, Center for European Governance and Economic Development Research Discussion Papers, no. 305, GeorgAugust Universität Göttingen, Germany.

Barrios S., Langedijk S., Pench L. (2010), EU fiscal consolidation after the financial crisis. Lessons from past experiences, Economic Paper 418, Dirección General de Asuntos Económicos y Financieros, Comisión Europea.

Bertola G. (2017), European unemployment revisited. Shocks, institutions, integration, „Research in Economics", vol. 71 no. 3, pp. 588-612.

Blanchard O.J. (2004), Explaining European unemployment, NBER Reporter, Summer.

Bajo-Rubio O., Díaz-Roldán C. (2009), Does the balance of payments constrain economic growth? Some evidence for the new EU members, „Post-Communist Economies”, vol. 21 no. 1, pp. 41-46.

Díaz-Roldán C. (2017), Fiscal performance in monetary unions. How much austerity should be allowed?, „Panoeconomicus”, vol. 64 no. 1, pp. 61-76, http://www.doiserbia.nb.rs/img/doi/1452595X/2017/1452-595X1600021D.pdf

Díaz-Roldán C. (2018), On the effectiveness of fiscal policies by the supply side in monetary unions, Universidad de Castilla-La Mancha, Ciudad Real, mimeo.

European Central Bank (2013), The importance and effectiveness of national fiscal frameworks in the EU, „Monthly Bulletin”, no. 2 (February), pp. 73-88.

European Commission (2008), Recommendation of the European Commission 2008/867/EC, of October 3.

European Commission (2017), Press release, May 30.

Gómez S., Gómez E., Bardí C., Barón J. (2016), El camino hacia el empleo juvenil, Observatorio empresarial contra la pobreza, Fundación Tomillo y Fundación CODESPA.

Picatoste J., Ruesga-Benito S., González-Laxe F. (2016), Economic sustainability and possibilities of action for the states, in the case of monetary integration. Some notes for reflection, „Progress in Industrial Ecology. An International Journal”, vol. 10 no. 1, pp. 16-33.

Rozmahel P., Grochová L.I., Liztman M. (2014), Evaluation of competitiveness in the European Union. Alternative perspectives, „Procedia Economics and Finance”, vol. 12, pp. 575-581. 